\title{
DEMOCRACIA E ESCÂNDALOS POLÍTICOS
}

\author{
Vera Chaia \\ Professora do Departamento de Política e do Programa de Estudos Pós-Graduados em Ciências Sociais da PUC-SP, \\ Pesquisadora do Núcleo de Estudos em Arte, Mídia e Política \\ Marco Antonio Teixeira \\ Pesquisador do Núcleo de Estudos em Arte, Mídia e Política da PUC-SP
}

\begin{abstract}
Resumo: Por meio de análise de alguns escândalos surgidos recentemente no cenário político brasileiro como os casos da violação do painel de votação do Senado Federal e das denúncias de corrupção no Banpará, Sudam e TDAs, busca-se compreender as determinantes dos escândalos repercutidos pela mídia, e analisar as conseqüências desses fenômenos para a política brasileira.

Palavras-chave: democracia; Estado brasileiro; Legislativo.
\end{abstract}

$\mathrm{U}$ ma série de escândalos marca o atual cenário político brasileiro, envolvendo senadores, secretários de governos e políticos de modo geral. A política nacional está vivendo uma crise peculiar com esses escândalos presentes em várias esferas da administração pública. Todos os envolvidos culpam a mídia por buscar casos escabrosos e denúncias contra personalidades públicas. O próprio Senado aparece como um poder comprometido com escândalos e sua credibilidade se encontra em xeque. Quais os elementos desencadeadores dos escândalos políticos? E que conseqüências esse fenômeno traz para a vida política brasileira?

Para abordar alguns casos de escândalos políticos que apareceram e ganharam destaque na mídia brasileira, será adotado um enfoque que privilegia a teoria social dos escândalos analisada pelo sociólogo inglês John B. Thompson, em seu recente livro sobre "Political scandal-power and visibility in the media age" (Thompson, 2000), no qual estuda escândalos políticos que envolvem corrupção, quebra de decoro parlamentar e escândalos sexuais.

Antes de examinar os escândalos políticos se faz necessário esclarecer o significado conceitual desse fenômeno, pois muitas vezes escândalo é confundido com corrupção, porém nem todo caso de corrupção se transforma em escândalo político. Nesse sentido, precisa-se diferenciar a análise do escândalo, dos estudos sobre a corrupção, uma vez que existem algumas especificidades que os diferenciam.

\section{ESTUDOS DA CORRUPÇÃO}

Alguns estudos estão mais preocupados em destacar os custos da corrupção para a sociedade, para as instituições e são prioritariamente casos e países que desenvolveram saídas políticas e souberam controlar o Poder Executivo, minimizando o aparecimento de corrupção. O próprio Banco Mundial, como agência financiadora internacional, avalia a necessidade de combater a corrupção, pois países com altos índices desses casos não são viáveis para se fazer investimentos. Portanto, os estudos de corrupção possuem um objetivo principalmente instrumental e moral e não propriamente científico, porque as causas e os elementos desencadeadores de casos de corrupção não são avaliados e tampouco destacados.

A Fundação Konrad-Adenauer lançou recentemente um caderno especial com o objetivo de analisar "Os custos da corrupção". Wilhelm Hofmeister, na apresentação, caracteriza a corrupção como "o maior obstáculo para o desenvolvimento. Ela aprofunda o fosso entre ricos e pobres, enquanto elites vorazes saqueiam o orçamento público. Causa distorções na concorrência, ao obrigar empresas a desviar importâncias cada vez maiores para obter novos contratos. Solapa a democracia, a confiança no Estado, a legitimidade dos governos, a moral pública. A experiência demonstra: a corrupção pode debilitar toda uma sociedade" (Fundação Konrad-Adenauer, 2000:7). 
Já o artigo de Bruno Wilheim Speck (2000), presente no caderno especial da Konrad-Adenauer, denominado "Mensurando a corrupção: uma revisão de dados provenientes de pesquisas empíricas", busca analisar as pesquisas que tiveram o objetivo de compreender e mensurar a corrupção.

$\mathrm{O}$ autor avalia o desenvolvimento dessas pesquisas e as sistematiza a partir dos seguintes elementos:

- pesquisas que privilegiam os "escândalos de corrupção" divulgados pelos meios de comunicação - os limites deste tipo de pesquisa esbarram na questão da liberdade de imprensa existente nos países e em possíveis mudanças nas editorias dos jornais, que poderão ou não privilegiar relatos sensacionalistas sobre casos de corrupção;

- indicador de corrupção construído a partir das condenações penais, com dados coletados na polícia, no Ministério Público e na Justiça - o mero registro não significa necessariamente a punição, e o significado de crime de corrupção também pode variar, pois os códigos penais não possuem o mesmo conteúdo de país para país;

- indicador de corrupção obtido através de pesquisas de opinião que auscultam "os cidadãos sobre o grau e a extensão da corrupção na sociedade" - envolve necessariamente avaliações subjetivas, porém foram muito utilizadas.

O tema da corrupção, portanto, entra na agenda política e a partir dos anos 90 se associa umbilicalmente às necessidades das reformas políticas e institucionais. Os relatórios do Banco Mundial, principalmente a partir do ano de 1996, são enfáticos em relação ao tema da corrupção e incentivam pesquisas que busquem detectar áreas e instituições "contaminadas" pela corrupção e que sejam alvo privilegiado de reformas estruturais e institucionais.

Flávia Schilling (1999), em um artigo intitulado "O Estado do mal-estar: corrupção e violência", argumenta que nos dias atuais o que prevalece nos noticiários são crimes envolvendo corrupção, tema presente na agenda política internacional e no Brasil a partir dos anos 80 e 90.

A autora afirma que a corrupção deve ser considerada crime e está associada à violência, com uma característica central: o exercício de influência concebido como "uma relação de forças entre as partes envolvidas a se equilibrar" (Shilling, 1999:48). Nesse sentido, a corrupção envolve também a coerção das relações de poder.

Um outro autor que estuda a corrupção na política brasileira é Marcos Otávio Bezerra, em seu livro Corrupção - um estudo sobre poder público e relações pessoais no Brasil, com o objetivo de analisar as "relações sociais que ordenam as práticas designadas como corruptas e corruptoras" (Bezerra, 1995:17). Para tanto, Marcos examina três "casos" - Valência, Capemi e Coroa-Brastel -, discutindo a lógica e os princípios sociais que fundamentam as condutas envolvidas nestes "casos".

Renato Janine Ribeiro (2000), no capítulo "da política da corrupção", do livro A sociedade contra o social -o alto custo da vida pública no Brasil, destaca como nos vários sistemas de governo, o tema corrupção teve significados diferenciados. Na tirania e na monarquia não havia a separação entre bem público e bem privado, portanto a corrupção estava associada a algum modo de traição à pátria, como nos desvios de conduta (basicamente sexuais) ou na acusação de mulheres, consideradas corruptas ao tentarem assumir papéis fora daquilo que a sociedade lhes passava como expectativa de boa conduta.

A corrupção, da maneira como nós a conhecemos, é um fenômeno da moderna República. Segundo o autor, o regime democrático, inevitavelmente, conviverá com algum grau de corrupção por diversas razões:

A primeira razão decorre do fato de a democracia pautar-se pelo sentimento de tolerância à diversidade, não havendo nenhum grau de afeto superior que padronize o comportamento das pessoas, como ocorria em épocas passadas quando se transformava em corrupção tudo aquilo que fugia dos padrões definidos pelo próprio grupo.

$\mathrm{O}$ segundo fator que explica a corrupção decorre da supremacia da sobrevivência individual (busca do dinheiro) em relação ao espaço coletivo (mundo do afeto). Nas estruturas (Estado) em que deveriam ser realizadas as produções de bens públicas, o interesse privado tem prevalecido.

Mas, o que vem se verificando é que, paralelamente ao pleno exercício da liberdade e do direito de fiscalizar e de escolher governantes, a corrupção também está presente nas democracias modernas, colocando em risco esse regime político. Ribeiro (2000:175-76) auxilia a melhor compreender esta situação paradoxal quando coloca que: "Talvez o melhor indício da situação claudicaste em que vive a República moderna, do ponto de vista da ética, apresente-se numa mudança quase despercebida, que afetou a palavra corrupção. Para os antigos, ela definia a degradação da coisa pública por meio da usura dos costumes. Hoje, ela se reduziu a coisa tão limitada como o mau trato do dinheiro público. Evidentemente, há uma ligação entre um sentido e outro. Para que funcionários ou magistrados exijam - ou aceitem - suborno, é preciso estarem desgastados os costumes; e é isso o que reduz a força do regime político que mais exige o respeito ao bem público: a democracia". 
Um outro enfoque da corrupção pode ser encontrado em Marcos Fernandes Gonçalves da Silva, (1995) no texto A economia política da corrupção: o escândalo do orçamento. $\mathrm{O}$ autor trabalha com as dimensões etimológica e normativa. No sentido etimológico, a palavra corrupção denota decomposição, putrefação, depravação, desmoralização, sedução e suborno. Já do ponto de vista normativo, o autor afirma que a corrupção envolve sempre um ato ilegal e que precisa de no mínimo dois agentes - um corrupto e um corruptor. Segundo Silva (1995:8), a corrupção no senso comum seria identificada: "como um fenômeno associado ao poder, aos políticos e às elites econômicas. Mas igualmente considera a corrupção algo freqüente entre servidores públicos (como policiais e fiscais, por exemplo) que usam o 'pequeno poder' que possuem para extorquir renda daqueles que teoricamente corromperam a lei".

\section{ESTUDO DE ESCÂNDALOS POLÍTICOS}

Freqüentemente escândalos e corrupção são confundidos, porém são fenômenos distintos e a relação entre os dois é variável. Sherman, citado por Marco Otávio Bezerra (1995:196), comenta que o escândalo envolve "estágios de desenvolvimento: revelação, publicação, defesa, dramatização, execução (julgamento) e rotulação".

Em sua obra, John B. Thompson (2000:13) tem como objetivo compreender o desenvolvimento dos escândalos políticos em diferentes culturas e países. Para tanto, o autor realiza uma análise sistemática do fenômeno do escândalo político, como produto da sociedade moderna, como também se preocupa em compreender as implicações que este fenômeno traz para a natureza e a qualidade da vida pública. Para Thompson, “'scandal' referes to actions or events envolving certain kinds of transgressions which become known to others, and sufficienthy serious to elicit a public response".

A emergência de um escândalo depende do conhecimento de outros, envolvendo um grau de conhecimento público sobre as ações e acontecimentos e a transformação desse conhecimento em 'making public' e 'making visible', através dos quais estas ações se tornam conhecidas dos outros. Nesse sentido, é crucial o papel da comunicação midiática na divulgação e publicização de vários escândalos.

Uma das características da comunicação midiática é a possibilidade de divulgar e de circular informações referentes a um determinado escândalo numa esfera que trans- cende o tempo e o espaço da sua ocorrência. O escândalo pode se espalhar rapidamente e de maneira incontrolável, sendo difícil reverter o processo, tanto que uma das conseqüências imediatas do escândalo político é o prejuízo que traz à reputação dos indivíduos envolvidos, portanto esse é um risco que sempre está presente quando um escândalo irrompe. Thompson considera que a reputação possui um 'symbolic power', pois é um recurso que os indivíduos podem acumular, cultivar e proteger.

Os indivíduos envolvidos em escândalos podem se defender de várias maneiras das acusações: entrar com uma ação na justiça e resolver os problemas numa corte legal; rejeitar as acusações, negar as transgressões ou negar que estejam envolvidos. Outra estratégia utilizada é a confissão pública, visando angariar simpatias dos outros com esse ato.

Corrupção pode se transformar em um escândalo. Quais as condições adicionais para que atividades corruptas se constituam em escândalos? A corrupção precisa ser descoberta para se tornar escandalosa, pois se as atividades de corrupção permanecerem escondidas dos outros estarão protegidas de uma futura investigação pública.

Corrupção envolve infração, violação de regras, convenções ou leis, que somente serão denunciadas se os outros (não-participantes) considerarem tais violações suficientemente sérias e importantes para serem reveladas e expressarem uma vigorosa desaprovação daqueles atos. Portanto, a articulação pública do discurso denunciatório é a condição final para que uma corrupção se transforme em um escândalo.

O escândalo não é um fenômeno novo, pois casos escandalosos, de vários tipos, existiram em muitos períodos da nossa história, mas com o desenvolvimento das sociedades modernas a natureza, a escala e as conseqüências dos escândalos sofrem alterações. Agora emergem os "escândalos midiáticos", que na avaliação de Thompson se caracterizam não só pelo fato de serem tratados pela mídia, mas por envolverem outra dimensão espacial-temporal e de extensão. Não são mais fenômenos localizados, pois podem adquirir também uma dimensão nacional e até global, exatamente pela expansão e desenvolvimento das comunicações.

Associados a esse desenvolvimento, Thompson destaca a profissionalização dos jornalistas e o surgimento do jornalismo investigativo. Agora, alguns jornalistas se consideram "guardiões do interesse público" e atuam no sentido de revelar os segredos dos poderes. Também não se pode deixar de considerar que existe um interesse comercial na divulgação dos escândalos, já que esse fenômeno 'vende'. 
Todos os cidadãos, em princípio, são iguais perante a lei, mas nem todos possuem visibilidade, porque não ocupam posições públicas importantes numa determinada sociedade. Existem indivíduos que são mais vulneráveis que outros, porque seu comportamento público, e também privado, está mais sujeito à exposição e ao controle e, portanto, mais sujeito a cobranças.

Um outro aspecto a ser considerado é que o surgimento do escândalo midiático está relacionado com transformações sociais do mundo moderno, redefinindo as relações entre a vida pública e a vida privada, uma vez que agora novas formas de visibilidade e publicização se fazem presentes, provocando novas relações entre escândalo e mídia e entre ações e interações sociais.

Autoridades públicas, a partir desse momento, adquirem um tipo de publicização que prescinde da presença física. Os governantes fazem uso da comunicação não somente como veículo para divulgação de decretos oficiais, mas também como meio de produzir a sua própria imagem. Portanto, a visibilidade presente nos dias atuais é benéfica para que as lideranças políticas sejam conhecidas, mas também deve ser avaliada com desconfiança, pois agora a mídia torna visíveis todas as atividades que estavam "escondidas" do público em geral e cria um campo complexo entre imagens e informações, fazendo que a visibilidade midiática se torne difícil de ser controlada e possa se transformar numa armadilha para as lideranças.

O desenvolvimento temporal do escândalo midiático também depende de outras instituições como justiça, instituições políticas e até policiais. Tal escândalo possui um começo e um fim, e se desenrola como um enredo de novela, envolvendo os espectadores e leitores que acompanham todas as etapas da "história". O término do escândalo pode implicar uma confissão, resignação, um inquérito oficial e um julgamento. Também existe a possibilidade desse escândalo desaparecer gradualmente da mídia, uma vez que já que não desperta interesse público.

Além dos indivíduos envolvidos diretamente no escândalo midiático, Thompson também ressalta que muitos e diferentes agentes e instituições podem estar envolvidos na criação e no desenvolvimento dos escândalos. Cita como exemplo a polícia e outros agentes da lei que freqüentemente possuem um papel crucial, pois realizam investigações das atividades que se tornaram "foco" do escândalo e contribuem com novos elementos, reforçando a necessidade de se investigarem esses escândalos.

Thompson pergunta: o que torna um escândalo um escândalo político? Um dos elementos que distingue o mero escândalo do político é que a arena de discussão é outra, implica lideranças políticas que estão envolvidas com o poder político num 'campo político' (definição utilizada por Pierre Bourdieu). Os escândalos podem aparecer em diferentes regimes políticos, desde os autoritários até aqueles em que predomina a democracia liberal. Porém, o regime que favorece a maior ocorrência dos escândalos políticos é a democracia liberal, porque possui algumas características que o diferenciam dos outros:

- a política é um campo de forças em competição, organizado e/ou mobilizado em torno de idéias, partidos e grupos de interesse;

- a reputação dos políticos é importante porque prevalece uma institucionalização do processo eleitoral e, para se ascender ao poder e obter sucesso eleitoral, um dos elementos-chave é gozar de boa reputação;

- a relativa autonomia da imprensa;

- as condições do poder político que favorecem a descoberta de transgressões por rivais e opositores, visto que prevalece o princípio da lei.

Ocorrem, portanto, escândalos políticos que envolvem questões sexuais, questões financeiras/corrupção e escândalos de poder, mostrando o mau uso ou abuso do poder.

\section{ESCÂNDALOS POLÍTICOS QUE ECLODIRAM NO GOVERNO DE FHC}

Será dentro desta ótica, deste enfoque, que serão estudados dois casos exemplares de escândalos políticos divulgados na última gestão do governo de Fernando Henrique Cardoso: a violação do painel do Senado e o caso Sudam (Superintendência do Desenvolvimento da Amazônia), Banpará (Banco do Estado do Pará) e TDAs (Títulos da Dívida Agrária), envolvendo o senador Jader Barbalho.

Para analisar os escândalos políticos optou-se por utilizar as revistas semanais ISTOÉ, da Editora Três, e a Veja, da Editora Abril. As duas revistas veicularam esses escândalos em várias edições e disputaram arduamente as manchetes de maior impacto, divulgando documentos e informações inéditas sobre os dois políticos envolvidos nos casos: ACM e Jader Barbalho. Enquanto a Veja centrava suas denúncias na figura de Jader Barbalho, a ISTOÉ, centrava-as em ACM.

Como compreender o atual momento político brasileiro no qual eclodem denúncias de escândalos envolvendo corrupção, quebra de decoro parlamentar, e outras tantas? Várias explicações podem ser dadas e dentre elas selecionamos 
as falas recentes de três atores políticos: o presidente Fernando Henrique Cardoso, o ex-governador do Ceará, Ciro Gomes, e o historiador José Murilo de Carvalho.

Numa entrevista dada ao jornal O Estado de S.Paulo (18/07/01:A4) o presidente Fernando Henrique Cardoso afirma que: "O novo que vivemos é que talvez pela primeira vez na nossa história a sociedade está passando a limpo, e o governo está deixando passar a limpo. Em vez de pensar que aumentou a taxa de corrupção, o que há é um reconhecimento (...) A sociedade está cobrando mais (...) O que está acontecendo é que o que chama a atenção é aquilo que aqui se chama de 'escândalos'(...) a mídia no Brasil tem a capacidade de antecipar processos e, assim, participa da criação de situações".

Uma matéria veiculada pelo jornal Folha de S.Paulo (20/07/01:A7) relata que Ciro Gomes está sendo processado pela Advocacia Geral da União, por ordem de Fernando Henrique Cardoso, por ter dito que o presidente "levou a corrupção ao centro do poder no Brasil", e o ex-governador, ao ser questionado de ter feito esta denúncia, diz, numa carta enviada à Executiva Nacional do PSDB, que reafirmará em juízo "sua doída convicção de que a corrupção exorbitou no Brasil nos últimos anos por omissão deste governo".

José Murilo de Carvalho por ocasião do lançamento de seu livro, Cidadania no Brasil - o longo caminho, foi entrevistado pelo jornal O Estado de S.Paulo (15/07/01:D4), fazendo a seguinte avaliação: "Quanto à corrupção, não creio que haja mais dela hoje do que antes. Violência e corrupção são endêmicas no País há 500 anos, são o nosso feijão-comarroz social. A novidade é que está havendo mais denúncias e investigações dos grandes ladrões - políticos, juízes, empresários -, em parte graças à melhoria na atuação do Ministério Público. É humilhante para o brasileiro, mas é um passo à frente para o cidadão".

Quais as verdades expressas por esses três atores políticos? É a sociedade que mudou? A mídia que cria fatos? O governo FHC que foi omisso tendo em vista manter a sua base governista? Ou a ação contra a corrupção foi produto da atuação mais contundente do Ministério Público? Todas essas ponderações devem ser levadas em conta para tentar explicar os escândalos políticos que iremos analisar no Senado Federal, em dois momentos de um mesmo processo: a violação do painel de votação do Senado envolvendo os senadores Antonio Carlos Magalhães (PFL) e José Roberto Arruda (PSDB) e o caso do Banpará, Sudam e TDAs, comprometendo o senador Jader Barbalho (PMDB).
Pode-se afirmar que a sociedade brasileira começou a mudar, não tolerando mais casos de corrupção e desmandos por parte das autoridades públicas no período pós-redemocratização e, principalmente, na gestão do presidente Fernando Collor de Mello (PRN), eleito diretamente pelos cidadãos brasileiros e derrubado através de um processo de impeachment, pelas mãos do Congresso Nacional e pelo povo brasileiro. As razões do processo que culminou no impeachment são várias, conforme literatura especializada, mas deve-se dizer que uma razão motivou a ação: indícios fortíssimos de corrupção em seu governo. Seu impeachment foi movido tendo por base a improbidade administrativa.

Também é desse período a Constituição Brasileira de 1988. Dentre as várias mudanças, uma se destaca: as alterações nas atribuições do Ministério Público, pois a partir desse momento ele ganha importância vital. "Conforme o capítulo IV, seção I do capítulo III 'Do Poder Judiciário' da Constituição da República Federativa do Brasil, promulgada em 1988, que rege sobre as funções e atribuições do Ministério Público, este poder é independente, separado dos poderes Executivo e Judiciário. Cabe ao Ministério, dentre outras funções, 'promover o inquérito civil e a ação civil pública, para a proteção do patrimônio público e social' (Constituição, p.92). Agindo nesse sentido, os procuradores ganharam destaque e transformaram-se, aos olhos da população, em paladinos da justiça e benfeitores dos cidadãos" (Chaia e Teixeira, 2000: 34-35).

A mídia também adquire importância nesse momento pois, além de contar com maior liberdade para se expressar, o jornalismo assume uma postura de jornalismo investigativo, sempre atento, denunciando, criando efetivamente fatos, e atuando em muitos casos como colaborador do Ministério Público e da Polícia.

\section{O GOVERNO FHC E O LEGISLATIVO}

Quando Fernando Henrique Cardoso assumiu a presidência da República em 1994, através de uma aliança eleitoral entre o PSDB e o PFL, articuladores políticos de seu governo se aproximaram do PMDB oferecendo ministérios e importantes postos no governo federal, visando garantir maioria parlamentar no Congresso Nacional e viabilizar a implementação das reformas estruturais que estavam sendo propostas pelo novo governo.

Com o sucesso do Plano Real e a alta popularidade de FHC, não foi difícil para os tucanos ampliarem a base 
governista com a adesão do PPB. Além de o presidente Fernando Henrique Cardoso ter conseguido uma ampla maioria no Legislativo, o que lhe garantiu a aprovação de medidas importantes para o seu governo, ele também aglutinou algumas grandes agremiações partidárias em torno de seu nome, conseguindo se reeleger para mais um mandato (19992002) à frente da presidência da República.

Ao formar uma base de sustentação parlamentar ideologicamente heterogênea, e com fortes contendas regionais, o governo federal também foi o fiador de uma composição política na qual o PSDB, PFL e PMDB passaram a se revezar no comando do Senado e da Câmara dos Deputados desde o primeiro mandato de FHC. Os presidentes da Câmara Federal no período 1995-2002 foram: Luís Eduardo Magalhães do PFL (1995-1996); Michel Temer do PMDB (1997-1998 e 1999-2000); e, atualmente, a casa é comandada por Aécio Neves do PSDB, até o final de 2002.

No Senado a presidência foi ocupada por grandes expoentes da política nacional: José Sarney do PMDB (19951996); Antonio Carlos Magalhães do PFL (1997-1998 e 1999-2000); e Jader Barbalho do PMDB, que assumiu o comando em fevereiro de 2001, ficando no cargo até outubro de 2001.

A busca de harmonia nas relações entre os poderes Executivo e Legislativo no Brasil guarda certa semelhança em todos os níveis de governo. A formação dos ministérios e secretariados e a distribuição do controle de cargos estratégicos na máquina pública refletem-se automaticamente na constituição das bases de sustentação governista no parlamento.

No âmbito federal, os estudos desenvolvidos por José Eisenberg (1998) e Otávio Amorin Neto (1998) demonstram que os governos que conseguiram maior estabilidade nas relações com o parlamento foram aqueles que montaram seus ministérios a partir da formação de coalisões com os partidos numericamente representativos no Poder Legislativo. A lógica adotada foi a de distribuir os cargos ministeriais de acordo com o tamanho proporcional das bancadas de partidos aliados.

Verifica-se, com isso, que o presidente FHC tem conseguido, ao longo desses sete anos de governo, manter o comando do Congresso Nacional entre os seus partidários, o que também significa que o Executivo vem influenciando na elaboração da agenda de trabalhos do Legislativo.

Porém, como os recursos existentes nem sempre são suficientes para contentar os diferentes interesses regio- nais, algumas disputas em torno do controle de bens públicos e do comando de órgãos estratégicos no Legislativo foram inevitáveis e colocaram a base governista em risco. Na briga por fatias de poder, a base de sustentação do governo FHC entrou em processo de erosão e líderes políticos de alto calibre começaram a se atacar, revelando ao país alguns fatos até então circunscritos aos corredores da arena política.

Desse modo, o Senado passou a viver sua maior crise política em 176 anos de existência. Entre junho de 2000 e maio de 2001, um senador foi cassado por suspeitas de desvios de dinheiro público e outros dois renunciaram aos seus mandatos por quebra de decoro parlamentar. Além disso, o atual presidente da casa foi constrangido por colegas a se licenciar do cargo em meio a uma série de denúncias que também o envolve em desvios de dinheiro público.

Neste trabalho, o ponto de partida será a hipótese de que as disputas por recursos do Plano Plurianual (PPA), também conhecido como Projeto Avança Brasil, e os desacordos dos partidos governistas em relação à sucessão das mesas diretoras nas duas casas legislativas, precipitaram a eclosão da crise no Senado e trouxeram a público uma série de informações até então restritas aos bastidores da política e que passaram a ter a dimensão de um escândalo político.

A seguir, será discutido o enredo desse escândalo, dando destaque aos fatores que o provocaram, bem como aos componentes políticos advindos de todo o processo que envolveu a renúncia de dois senadores e as suspeitas de corrupção que recaem sobre o atual presidente da casa.

\section{OS PERSONAGENS E O ENREDO DA CRISE NO SENADO}

Antonio Carlos Magalhães (ACM), Jader Barbalho e José Roberto Arruda foram os principais personagens da crise política que tomou conta do Senado Federal. Senadores experientes, com longas passagens pelo Executivo, e que possuem um traço comum: foram articuladores políticos do governo FHC em momentos decisivos para os interesses de sua gestão.

Diferentemente do que se pensa, os problemas no Senado não tiveram origem na disputa pelo comando da mesa diretora da casa durante o ano 2000. Os conflitos entre Jader e ACM se iniciaram em 1999, quando disputavam o controle da relatoria do Plano Plurianual (PPA) para o quadriênio 2000-2003, um conjunto de 
políticas sociais do governo que foi batizado de Programa Avança Brasil. ${ }^{1}$

Com um volume de recursos em torno de $\mathrm{R} \$ 1,1$ trilhão, a disputa pela relatoria do PPA provocou uma verdadeira guerra entre os dois parlamentares com a anuência do governo federal. De acordo com a revista ISTOÉ, "irritado com os pitos públicos que tem recebido de ACM, Fernando Henrique simplesmente estimulou Jader a medir forças com 'Toninho Malvadeza"'.

No decorrer dessa disputa, ambos já haviam protagonizado uma série de trocas de acusações no melhor estilo "lavagem de roupa suja em público". Jader acusou ACM de ser sócio do ex-banqueiro Ângelo Calmon de Sá, antigo proprietário do falido Banco Econômico, numa empresa situada no paraíso fiscal das Ilhas Cayman. As ilações feitas por ACM ao seu adversário também não eram novas; o senador baiano denunciou que Barbalho havia provocado um desfalque no Banpará, no período em que governou aquele Estado (ISTOÉ, 29/09/99, n ${ }^{\circ}$ 1.565).

Derrotado por Barbalho, ACM iniciou um processo de isolamento político que fez aumentar ainda mais seu distanciamento do Palácio do Planalto, apesar de continuar mantendo o controle de dois importantes ministérios: o das Minas e Energia, comandado por Rodolpho Tourinho, e o da Previdência Social, que tinha à frente o atual senador Waldeck Ornelas. O governo federal, por sua vez, dava sinais de maior aproximação com o PMDB em detrimento do PFL.

Paralelamente a essa conturbada disputa entre os dois grandes personagens da política brasileira, seguiam as investigações sobre o escândalo da construção da sede do TRT de São Paulo, que envolvia o senador Luiz Estevão do PMDB-DF com denúncias de participação num esquema de superfaturamento da obra do TRT (Tribunal Regional do Trabalho) paulista e de desvio de recursos. Estevão, que havia sido sub-relator do PPA, estava sendo investigado pelo próprio Senado.

Em junho de 2000, após um ano e dois meses de processo, Luiz Estevão passou para a história política do país não só como o primeiro senador cassado, mas também pelo fato de que o episódio da violação do painel com os votos dos senadores ocorreu na sessão em que se votou a perda do seu mandato. O posicionamento de cada senador, que deveria ter ficado em segredo, começava a ser veiculado nos bastidores do poder pela voz da principal autoridade da Casa: o senador Antonio Carlos Magalhães.

No Senado, todos sabiam que ACM havia conseguido, de forma ilegal, obter a lista com o posicionamento dos se- nadores naquela votação, mas ninguém questionava sua conduta oficialmente. Por que isso? Estava caracterizada a suspeita de quebra de decoro parlamentar envolvendo o senador Antonio Carlos Magalhães, por que não investigá-lo?

As respostas para essas questões talvez estejam associadas à conjuntura política daquele momento, ainda extremamente favorável ao senador baiano. Além de presidente do Senado, ele era tido como um dos homens mais fortes da política nacional por comandar o PFL, um dos principais pilares de sustentação parlamentar do governo federal. ACM usava de chantagens contra colegas e os desqualificava, sempre transgredindo o Código de Ética e Decoro Parlamentar da casa e sem nunca sofrer qualquer tipo de sanção por seus atos.

A imprensa que poderia trazer a público essas questões estava mais interessada no emaranhado político envolvendo a eleição das mesas do Senado e da Câmara Federal, em que Jader e o próprio senador Antonio Carlos já se agrediam mutuamente pelo controle da sucessão.

A violação do painel do Senado ainda não havia ganhado o status de escândalo político porque o enredo de sua história ainda não era de domínio público. Numa casa legislativa onde sua principal autoridade mandava os colegas "calarem a boca", essas questões não tinham a dimensão de uma transgressão. A posição de ACM era tão confortável a ponto de ele usar estrategicamente a suposta lista para constranger os senadores que de alguma forma o contrariassem.

\section{A SUCESSÃO NO CONGRESSO NACIONAL}

A crise no Senado Federal acabou ganhando dimensão pública com a disputa pela sucessão da mesa diretora, protagonizada por Antonio Carlos Magalhães e Jader Barbalho. Após quatro anos à frente do comando da casa, ACM rejeitava a idéia de passar a presidência para o parlamentar peemedebista, principalmente após ter sido derrotado politicamente por Jader durante a escolha da relatoria do PPA.

Nessa briga ACM não estava sozinho, o PFL também havia sido preterido pelo governo federal na sucessão da Câmara dos Deputados. Um acordo entre o PSDB e o PMDB acabou garantindo a presidência do Senado para os peemedebistas e a presidência da Câmara dos Deputados para os tucanos. Por isso, ACM começou a mover todos os esforços na busca de um nome alternativo ao de Jader e também no sentido de desqualificar moralmente o senador paraense a fim de tornar sua candidatura inviável. 
A briga entre os dois estava se transformando num espetáculo para a imprensa. Durante uma sessão do Senado, ambos acabaram levando suas divergências para a tribuna e protagonizando um dos piores momentos da casa. ACM se referiu a Jader Barbalho como "Corrupto, ladrão, bajulador, truculento, mentiroso e indigno". O senador peemedebista não deixou por menos e enfrentou o presidente da casa chamando-o de "Corrupto, ladrão, truculento, farsante e mentiroso". Essa troca de farpas fez com que a imprensa nacional passasse a dar ampla cobertura ao processo sucessório no Senado.

Os principais telejornais noturnos levaram ao ar as imagens com a troca de insultos. As emissoras de rádio, como a CBN e a Rádio Eldorado, trouxeram em suas programações jornalísticas os discursos de ambos no momento em que se agrediram verbalmente. Os grandes jornais de circulação nacional deram destaque para o conflito, reproduzindo nas matérias os trechos em que trocaram acusações.

Apesar de haver punição prevista para a troca de insultos dessa natureza, nenhum dos dois senadores foi, efetivamente, alvo de qualquer processo interno. ${ }^{2}$ Esse era apenas o início de capítulos mais apimentados envolvendo a sucessão, e a partir daí surgiu uma verdadeira guerra de dossiês que culminou no lançamento de livros em que cada um procurava desqualificar moralmente o seu adversário.

Seguindo a trajetória de revelar as supostas mazelas da vida pessoal dos principais personagens do Senado, a revista Veja $\left(25 / 10 / 2000, n^{\circ} 1.672\right)$ partiu para o ataque contra o senador paraense. Em sua reportagem de capa, que trouxe a fotografia de um Jader Barbalho sisudo, acompanhado da manchete "O senador de 30 milhões de reais", destacou também que "nos últimos 34 anos, Jader Barbalho só não ocupou cargos públicos durante 11 meses. Mas, apesar da labuta na política, conseguiu erguer uma fortuna surpreendente".

A revista demonstrou que o patrimônio do senador peemedebista saltou de R $\$ 61.200,00$ (corrigidos em valores atuais) em 1974, para cerca de $\mathrm{R} \$ 30.000 .000,00$ no ano 2000. Obviamente, o peemedebista atribuiu ao senador Antonio Carlos Magalhães a autoria do conteúdo que estava sendo veiculado na citada reportagem.

Apesar do impacto negativo sobre a sua imagem na opinião pública, Jader Barbalho continuou favorito na corrida para a presidência do Senado. A repercussão da reportagem não trouxe qualquer estrago para a aliança de seu partido com o PSDB.

O tempo corria contra o senador baiano e não havia mais possibilidades de inviabilizar a articulação política que se formou em torno do político paraense. Restou ao PFL lançar candidatos para marcar posição, pois sua derrota era tida como inevitável. Para a Câmara dos Deputados foi lançado o nome de Inocêncio de Oliveira do PFL e para o senado, Arlindo Porto do PTB.

A derrota do PFL se concretizou. Na Câmara, a vitória foi de Aécio Neves do PSDB que se elegeu com 55\% dos 512 votos, ficando o pefelista Inocêncio de Oliveira com $23 \%$. No Senado, Jader Barbalho obteve $51 \%$ dos 81 votos apurados e venceu o candidato apoiado pelo PFL que ficou com $35 \%$.

Quem imaginava que as brigas entre ACM e Jader iriam parar por aí, se enganou. Desgostoso com mais essa derrota, o senador Antonio Carlos Magalhães passou a atacar o governo FHC e numa jogada política arriscada trouxe de volta a público, mesmo que involuntariamente, o caso da violação do painel do Senado.

Foi desse modo que a crise do Senado começou a ganhar o status de escândalo político, conquistando espaço na mídia e chamando a atenção da população justamente pelo fato de os senadores estarem protagonizando cenas que não combinavam com a função pública para a qual foram eleitos.

\section{O PAINEL DO SENADO E AS RENÚNCIAS DE ACM E ARRUDA}

Em 19 de fevereiro de 2001, o então senador Antonio Carlos Magalhães conversou reservadamente com os procuradores da República Luiz Francisco de Souza, Guilherme Schelb e Eliana Torelly. Tinha como objetivo fazer uma série de denúncias contra o governo FHC e Jader Barbalho, requentar velhos assuntos como o caso Eduardo Jorge, os desvios de recursos no Ministério dos Transportes e as suspeitas de corrupção sobre o seu principal desafeto político.

O procurador Luiz Francisco de Souza gravou "secretamente" a conversa com ACM e logo em seguida revelou seu conteúdo para a revista semanal ISTOÉ. Na sua edição 1.639 (22/02/2001), a revista trouxe a público o conteúdo da conversa, dando início ao calvário político do senador baiano, outrora todo poderoso da República. A publicização dos "segredos" revelados por Antonio Carlos Magalhães fez com que o mundo se voltasse contra ele próprio.

Apesar de ter revelado muitas questões que já havia dito em outros locais públicos, como os corredores do Senado, a diferença foi que desta vez havia uma fita gra- 
vada. Nela, o próprio ACM afirmava ter conhecimento da existência de uma lista com os votos dos senadores na sessão que cassou o senador Luiz Estevão em junho de 2000 e revelava a suposta posição da senadora Heloísa Helena do PT contra a cassação de Estevão.

O procurador que revelou a conversa para a imprensa passou a ser tratado com reservas pelos seus próprios colegas que chegaram a ameaçá-lo de não mais trabalhar com ele. A própria imprensa nacional começou a tratar Luiz Francisco com descaso, colocando em dúvida a sua capacidade para o exercício da profissão. Alguns políticos o tripudiaram chegando a propor o seu afastamento do cargo. Sem entrar no mérito da atitude de Luiz Francisco, foi inegável sua contribuição para o redirecionamento dos rumos políticos do país ao revelar publicamente a conduta de um dos homens mais poderosos da era FHC.

A ação do procurador Luiz Francisco trouxe à tona uma questão muito cara para a vida contemporânea: os bastidores da política possuem uma dinâmica própria e raramente os cidadãos são informados do que está sendo "tramado" pelos políticos, ou, em muitas ocasiões, não conseguem acompanhar nem mesmo as atividades rotineiras com dimensão mais pública. ${ }^{3}$

O Ministério Público ganha visibilidade e mais autonomia a partir de 1988, conforme apontado anteriormente. Rogério Bastos Arantes, em sua pesquisa sobre o Ministério Público e política no Brasil (Arantes, 2000:55), afirma que "(...) a garantia de independência no exercício de suas funções tem permitido que promotores e procuradores de justiça atuem com extrema desenvoltura e autonomia - particularmente nos conflitos de dimensão social e política - contra as pressões externas, e até mesmo internas, advindas dos estratos superiores da instituição".

Existe, portanto, um problema de desconexão entre a atividade política e toda a sociedade. É exatamente nesse vazio que a imprensa e o Ministério Público vêm ocupando o espaço por trazerem para a população aquilo que é restrito, que é segredo e que é negociado nos bastidores da política.

A revelação dos fatos pela revista ISTOÉ trouxe conseqüências imediatas: estava caracterizada a possibilidade de quebra de decoro parlamentar por parte do ex-presidente do Senado. ${ }^{4}$ Além disso, o presidente Fernando Henrique Cardoso demitiu os dois ministros indicados por ACM e em seguida também afastou todas as pessoas de sua confiança que ainda ocupavam cargos em algum órgão do governo federal.

Presidido por Jader Barbalho, o Senado contratou um grupo de peritos vinculados à Unicamp para avaliar a pos- sibilidade do painel ter sido violado. Paralelamente, Antonio Carlos Magalhães adotou como estratégia negar todo o noticiário veiculado pela imprensa e colocar em dúvida a veracidade das fitas. Por outro lado, a própria revista ISTOÉ se encarregou de contratar um perito para avaliar a possibilidade de as gravações não serem verdadeiras.

A situação do senador baiano se complicou ainda mais, em 3 de março de 2001. A revista ISTOÉ, em sua edição $\mathrm{n}^{\circ} 1.640$, publicou a transcrição de vários trechos da conversa de ACM com os procuradores da República e divulgou o laudo elaborado pelo perito Ricardo Molina confirmando a autenticidade das fitas.

Todo o material coletado pela revista, mais o fato de os peritos contratados pelo Senado também terem confirmado a possibilidade de violação do painel de votação, acabou se constituindo em provas contra a versão dada por Antonio Carlos Magalhães. A abertura de uma Comissão de Ética tornou-se inevitável, pois a mentira foi considerada uma falta grave e isso reforçou ainda mais a necessidade de verificar a possível quebra de decoro parlamentar.

Instalada em 13 de março, os primeiros depoentes na Comissão de Ética foram os jornalistas da ISTOÉ, Andrei Meireles, Mino Pedrosa e Mário Simas Filho, que confirmaram o teor das fitas. Na mesma sessão foram tomados os depoimentos dos procuradores Guilherme Schelb e Eliana Torelly, que não responderam às perguntas elaboradas pelos senadores.

A partir daí, uma série de contradições marcou os depoimentos de funcionários do senado e do Senador Antonio Carlos Magalhães. A ex-diretora de informática do Senado, Regina Borges, em seu primeiro depoimento negou que houvesse violado o painel e também rejeitou a hipótese de que algum senador tivesse lhe pedido que realizasse tal serviço.

Constrangida pelo fato de outros funcionários do senado não terem confirmado a sua versão, Regina Borges voltou atrás em relação ao depoimento anterior e revelou que havia copiado a lista de votação a pedido do senador José Roberto Arruda do PSDB, então líder do governo, e que ele havia feito a solicitação em nome do presidente da casa, o senador Antonio Carlos. Sua declaração caiu como uma bomba em Brasília e a partir daquele momento ACM não seria mais o único réu.

$\mathrm{O}$ caso passou a ganhar a conotação de um evento de grande interesse público para a imprensa. Duas emissoras de canal fechado transmitiram os depoimentos dos senadores e da ex-diretora de informática ao vivo: a Globonews 
e a TV Senado. As principais redes de televisão também abriram espaços na sua programação para o escândalo: a TV Cultura e a Rede Bandeirantes entraram ao vivo no momento dos principais depoimentos e as redes Globo, Record, RedeTV e SBT passaram flashes do Senado em vários momentos de suas programações. As emissoras de rádio também reproduziam os depoimentos diretamente do local em que se reunia a Comissão de Ética.

$\mathrm{O}$ fato de a imprensa ter dado holofotes ao caso rompeu com o hiato entre a população e os fatos que estavam acontecendo no Senado. Foi essa cobertura mais explícita que impediu a possibilidade de se "costurar" qualquer acordo político para salvar os dois senadores. As investigações em curso ganharam visibilidade e todas as declarações sobre o caso eram calculadas para que não houvesse prejuízo na opinião pública.

Desse modo, todos os envolvidos com o escândalo estavam dialogando não apenas com os seus colegas no Senado, mas também com um vasto contingente populacional que passou a acompanhar as sessões da Comissão de Ética como se fosse um filme, de cuja história já se sabia o começo e o desenrolar, restando apenas descobrir qual seria o seu final.

No plenário do Senado, no dia de 17 de abril, Antonio Carlos Magalhães afirmou aos colegas que: "não recebi lista nenhuma nem me foi entregue por ninguém lista alguma" (Veja, 02/05/2001, no 1.698).

Também indignado com o envolvimento de seu nome por Regina Borges, José Roberto Arruda subiu à tribuna do Senado em 18 de abril para afirmar que: "Nunca vi nenhuma lista. Nunca a pedi nem a recebi. Nunca fui informado sobre ela. O senador Antonio Carlos Magalhães nunca fez nenhuma consideração a esse respeito comigo". Ao perceberem que o depoimento da ex-diretora de informática havia ganhado confiança da opinião pública, senadores resolveram mudar suas versões sobre os fatos, numa tentativa desesperada de conquistar a opinião pública com o reconhecimento do erro que cometeram.

$\mathrm{O}$ primeiro a assumir publicamente que mentiu foi o senador José Roberto Arruda. Emocionalmente abalado, o já ex-líder do governo e também ex-tucano subiu à tribuna do Senado para confessar ter encontrado a ex-diretora do setor de informática, de quem recebeu a lista de votação, e tê-la entregue a Antonio Carlos Magalhães. Encerrou o seu discurso afirmando que "é inútil resistir à verdade" (Folha de S.Paulo, 24/04/2001, Caderno Brasil).

Ao pedir desculpas aos colegas e à população pela mentira, José Roberto Arruda estava tentando conquistar a compaixão da opinião pública e a partir disso evitar sua cassação. O próprio presidente Fernando Henrique Cardoso chegou a qualificar o discurso de seu ex-líder no Senado como "corajoso", mas diante da repercussão negativa acabou não comentando mais tal caso.

Alguns dias depois, foi a vez de ACM mudar a sua versão anterior e confessar ter recebido a lista do senador José Roberto Arruda, verificado voto por voto e depois disso afirmou que a destruiu. Para tentar amenizar sua culpa disse não ter solicitado a relação com os votos dos senadores "nem direta nem indiretamente". Apesar disso, ACM não conseguiu explicar porque mentiu para os colegas quando usou a tribuna do Senado para negar a existência da lista, e também não foi convincente ao justificar não ter tomado providências para investigar a violação do painel por "razões de Estado". ACM, em seu depoimento, afirmou temer que a descoberta da violação do painel pudesse tornar nula a sessão que cassou Luiz Estevão.

Esse desmentido foi intensamente veiculado pelos meios de comunicação, e muitos deles compararam os depoimentos dados pelos senadores em diferentes momentos para mostrar os pontos de contradição existentes em cada um. Para a população a sensação que ficava era a de sucessivas mentiras, a cassação dos senadores era inevitável e não haveria articulação política que fosse suficiente para barrá-la.

Na seção de Cartas da revista Veja, os leitores puderam se manifestar: "Os senadores Antonio Carlos Magalhães, José Roberto Arruda e Jader Barbalho pensam que os eleitores brasileiros são cidadãos de quinta categoria, eles fazem o que querem e o povo não entende nem aceita. Quero dizer para esses senhores que temos memória, sim, que não queremos mais a corrupção que assola o país. Eles que não venham se mostrar como mocinhos injustiçados. Perto deles o juiz Lalau é mocinho de recados" (Otavio Oliveira, Belém, PA - 02/05/01, n 1.698).

Assim, a Comissão de Ética, presidida pelo senador Ramez Tebet, do PMDB de Mato Grasso do Sul, concluiu pela cassação dos dois senadores. Com o relatório elaborado por Saturnino Braga, do PSB, aprovado por 13 votos a dois em 23/05/01, não restou outra alternativa aos envolvidos senão renunciar ao mandato, caso contrário teriam seus direitos políticos suspensos por oito anos. Assim, Arruda renunciou em 24 de maio e no dia 30 de maio de 2001 foi a vez de Antonio Carlos Magalhães.

A revista $I S T O E ́$, em sua edição $\mathrm{n}^{\circ} 1.652$, comemorou afirmando que a "derrocada de ACM começou com a reportagem de ISTOÉ que revelou as conversas do senador 
com procuradores da República". Isso nos remete à seguinte dúvida: por que a questão da violação do painel não veio à tona logo após a cassação de Luiz Estevão, já que ACM falava pelos quatro cantos do Senado que conhecia a tal lista? Talvez a revista tenha razão em arvorar para si todo o mérito desse processo, pois foi ela quem conseguiu provas por meio "da voz do delator" e legitimada pelo Ministério Público, uma instituição que vem ganhando credibilidade pública justamente por estar agindo contra as mazelas do mundo político.

\section{O CASO JADER BARBALHO}

Todas as denúncias contra Jader Barbalho acabaram sumindo da agenda política da imprensa no período em que os casos dos senadores Antonio Carlos Magalhães e José Roberto ganharam maior visibilidade. Porém, isso não significou que as suspeitas de desvios de dinheiro público envolvendo o político paraense houvessem caído no esquecimento. Novamente, a revista Veja agiu como um veículo de jornalismo investigativo, retomando o assunto.

Convém relembrar que foi a mesma revista que trouxe, em outubro de 2000, uma longa reportagem sobre a evolução do patrimônio de Barbalho, além de relembrar diversos episódios que o envolveram com suspeitas de corrupção. Como o político paraense estava disputando a presidência do Senado, essas questões acabaram sendo vistas como parte da estratégia de ACM em desgastá-lo. Com isso, nem os tucanos, que mantiveram o apoio à candidatura Jader Barbalho, e muito menos a opinião pública, informada sobre as tramas que envolvem os bastidores da política, levaram a sério o que se falava sobre ele.

Por isso, o próprio Jader, além de desmentir publicamente a reportagem da Veja na tribuna do Senado, vinculou-a a uma iniciativa de Antonio Carlos Magalhães. Essa estratégia deu certo enquanto ele disputava a presidência do Senado e lhe trouxe mais alívio com a deflagração da crise do painel eletrônico.

Porém, sua situação começou a se agravar no momento em que as fontes oficiais que investigavam os desvios de recursos no Banpará e na Sudam concluíram pelo envolvimento do senador. Mesmo assim ele insistia em desmentir qualquer envolvimento do seu nome com os citados casos.

Sobre a incompatibilidade de seu patrimônio com a sua renda, denunciada pela Veja $\left(02 / 05 / 2001, \mathrm{n}^{\circ} 1.698\right)$, Jader tentou por meio de uma auditoria da empresa Boucinhas
\& Campos rechaçar as acusações de enriquecimento ilícito. Mas a própria revista se encarregou de desmentir a versão do senador ao verificar as contradições existentes nas informações que foram analisadas pela auditoria com as da declaração de patrimônio feita pelo próprio senador no TRE (Tribunal Regional Eleitoral) paraense. Configurava-se, assim, uma primeira contradição em relação ao discurso proferido por ele na tribuna do Senado na tentativa de se defender das acusações da revista Veja.

Com relação à acusação de desvios de recursos da Sudam, Jader negava-os e também qualquer tipo de ligação com os superintendentes que haviam sido demitidos por corrupção. Recaía sobre o senador a suspeita da cobrança de um "pedágio" de $20 \%$ para que os projetos enviados à Sudam fossem aprovados.

As investigações acabaram levando a um grande fraudador da Sudam, o empresário José Osmar Borges, que havia se beneficiado de seis projetos aprovados no órgão e estava sendo acusado de desviar $\mathrm{R} \$ 133$ milhões da instituição. Um documento levantado pela revista Veja (18/04/2001, $\left.\mathrm{n}^{\circ} 1.696\right)$ na Junta Comercial do Pará colocou Jader Barbalho como sócio do possível fraudador. Mais uma vez, as versões do senador eram desmentidas pelo veículo de comunicação, corroborando ainda mais um pedido de quebra de decoro parlamentar por mentir em público.

Corre ainda contra o senador paraense outras duas denúncias: a venda fraudulenta de TDAs no período em que ele era ministro; e de ter participado de um esquema que provocou um rombo de $\mathrm{R} \$ 10$ milhões no Banpará.

Quanto aos TDAs, eles se referiam à desapropriação de uma fazenda no Estado do Pará que só existia no papel. Apesar de negar sua participação na operação fraudulenta, o senador teve sua versão contestada por outras pessoas que participaram do "negócio".

Com relação ao caso Banpará, a mesma revista Veja $\left(02 / 05 / 2001, n^{0} 1.698\right)$ trouxe documentos mostrando a existência de recursos que foram desviados para as contas correntes de Jader Barbalho e de seus familiares. Ao tentar se defender, o senador alegou que o relatório do Banco Central não o incriminou. No mesmo dia, Gustavo Loyola, ex-presidente do Banco, afirmou que o nome de Jader só não constava da folha de rosto do relatório, pois nas páginas seguintes o senador era citado pelo menos 17 vezes.

O caso Jader acabou tendo um desfecho semelhante aos de ACM e Arruda no que se refere ao seu encaminhamento no Senado. O procurador-geral da República já solicitou a quebra do sigilo bancário do senador, retroativa aos 
anos 80, para investigar a venda irregular de TDAs. Se o pedido for aceito pelo Supremo Tribunal Federal (STF), o órgão também deverá solicitar a abertura de processo judicial (Veja, 01/08/2001, no 1.711).

Foi essa série de desmentidos das versões dadas por Jader Barbalho que se transformou no principal motivo para a convocação de uma Comissão de Ética para avaliar a existência, ou não, da quebra de Decoro Parlamentar por parte do político paraense.

Com isso, se iniciou um rápido processo de debilitação política de Jader. Em menos de seis meses, Barbalho viu sua condição de presidente do Senado ser substituída pela de senador-licenciado, e logo em seguida, com o encerramento dos trabalhos da Comissão de Ética que conclui pela existência da quebra de Decoro Parlamentar, se viu forçado a renunciar para preservar seus direitos políticos e tentar um retorno à vida pública disputando as eleições de 2002 como candidato ao governo do Pará ou até mesmo concorrendo a uma vaga no Senado.

\section{CONSIDERAÇÕES FINAIS}

A crise política no Senado teve com um de seus focos de origem as disputas entre Jader Barbalho e Antonio Carlos Magalhães pelo controle dos recursos do programa Avança Brasil. Se, por um lado, o governo federal conseguiu formar uma sólida maioria parlamentar ao aglutinar em torno de si forças políticas tão heterogêneas, por meio do oferecimento do controle de cargos públicos, por outro, o próprio Executivo se tornou refém dessa estratégia ao ver seus aliados praticamente paralisarem as atividades do Legislativo em função dos conflitos por interesses específicos por eles protagonizados. Fica claro que a estratégia de se construir uma maioria parlamentar governista por intermédio da troca de cargos na máquina pública, ao mesmo tempo que pode trazer segurança na tramitação dos projetos do Executivo, pode também significar o início do seu calvário. Os órgãos controlados pelos parlamentares, se não sofrerem controle social, poderão estar sujeitos a uso indevido ou até mesmo de serem alvos da ação de corruptos.

No caso da violação do painel do Senado, ficou evidente que sua visibilidade pela imprensa deu a ele o status de escândalo político. Enquanto o assunto esteve confinado aos corredores do Senado, parecia ser mais uma das "compreensíveis" atitudes de um presidente da casa que já estava habituado a dirigi-la como se fosse um órgão de sua propriedade. Até que o caso chegasse a pú- blico, os próprios senadores não o consideravam uma falta grave.

Também é importante lembrar, foi na tentativa de ACM revelar alguns "segredos" comprometedores da reputação de personalidades públicas, por ter se sentido preterido pelo governo federal na distribuição de recursos públicos e no controle do comando do Senado, que essas questões ganharam toda a repercussão. Aqui ganha força a tese de que os conflitos podem levar à revelação de "segredos públicos" e torná-los visíveis aos olhos de todos. Não fosse essa contenda malresolvida entre ACM, Jader e o governo federal, talvez a população não soubesse de tudo o que hoje tem sido revelado publicamente.

Destaca-se também, que em ambos os casos estudados, a imprensa e o Ministério Público tiveram um papel fundamental na mobilização da opinião pública. Coube aos meios de comunicação e ao Ministério Público ocupar um espaço vazio entre a arena política e a sociedade. Com a repercussão dos fatos trazidos a público, tanto a imprensa como o Ministério Público acabaram se transformando, aos olhos da população, em entidades fiscalizadoras dos interesses da sociedade.

Como os cidadãos pouco sabem sobre o que realmente ocorre nos centros decisórios do poder e cada vez mais desconfiam das boas intenções da classe política, a imprensa e o Ministério Público acabaram se tornando referências positivas justamente por andarem em tensão com o mundo político e revelarem não só as mazelas de senadores, como também as tramas que muitas vezes percorrem as entranhas do poder.

O aparecimento de "escândalos midiáticos" é resultado de um jornalismo investigativo e possui pontos positivos e negativos. Por um lado, a divulgação desses escândalos provoca um aumento da fiscalização das atividades políticas, forçando que sejam criados instrumentos para seu controle, e por outro, a cobertura desses escândalos pode levar a uma generalização dos "maus exemplos" de políticos, provocando descrença nas instituições, consideradas como inoperantes e custosas.

Essa descrença pode ser apreendida na última pesquisa feita pelo Ibope, quando foram entrevistadas 5.300 pessoas em nove capitais e interior de São Paulo. Ao serem perguntados se os políticos se preocupam com o bem-estar da população, o eleitorado de algumas capitais demonstrou que acredita muito pouco no político brasileiro: Brasília 2,98\%; Porto Alegre, 3,21\%; Recife, 4,53\%; Rio de Janeiro, 5,42\%; São Paulo, 5,48\%; Curitiba, 6,06; Belo Horizonte, 6,39\%; Fortaleza, 
6,79\%; Salvador, 7,33\%; São Paulo (interior), 8,87\% (Veja, 25/07/01, no 1.710).

Portanto, existe uma complementaridade dos campos político e midiático. A alimentação dos escândalos políticos também se deve à concorrência política. No caso específico deste estudo, pode-se afirmar que a guerra de dossiês obedeceu a um objetivo político de isolar ACM do poder. O caso Jader Barbalho é rescaldo desse processo e sua retirada de cena também é necessária.

$\mathrm{O}$ caso Jader Barbalho vincula-se a um dos principais problemas decorrentes da construção de uma maioria parlamentar por meio da troca de postos na máquina pública. Essa estratégia de formação da base governista fragiliza o controle do Legislativo sobre a administração pública, pois o parlamentar que deveria atuar como um fiscal do bom uso dos recursos públicos acaba se tornando parte integrante do Poder Executivo.

Se o governo dessa forma consegue aprovar seus projetos no Legislativo, ele deixa, no entanto, os bens públicos sob o controle de políticos que na maioria das vezes agem orientados por seus interesses pessoais e eleitorais. Com isso, as fronteiras entre os interesses público e privado não ficam bem-definidas.

O ex-senador Antonio Carlos Magalhães, que como autoridade política com poder era ouvido constantemente pela mídia e considerado fonte privilegiada, recolheu-se estrategicamente na Bahia ("a Bahia está comigo"), desapareceu dos noticiários e somente foi relembrado por ocasião do episódio Jader Barbalho, aparecendo para reafirmar suas denúncias contra este político.

Os escândalos políticos ganham destaque na democracia exatamente por ser um regime político em que os conflitos e atritos políticos se tornam mais presentes e visíveis. A concorrência política e a busca de cargos também acelera as contendas políticas. No caso dos escândalos estudados, os confrontos ficaram claros e a necessidade de se derrotar o inimigo são explicitadas a todo o momento. As denúncias que envolveram Jader Barbalho já eram públicas e a lista com os votos dos senadores por parte de ACM já era conhecida. Mesmo assim, os senadores continuaram atuando politicamente como se não estivessem envolvidos nesses escândalos políticos, porque acreditavam na impunidade tão presente na vida pública brasileira e se resguardavam por trás da imunidade parlamentar. A reputação desses três senadores está comprometida seriamente, pois as transgressões foram descobertas e divulgadas publicamente pela mídia. Resta perguntar qual será o futuro político desses personagens da nossa história.

\section{NOTAS}

E-mail dos autores: vmchaia@pucsp.bre macteixeira@uol.com.br

1. O Plano Plurianual é o principal instrumento de planejamento de médio prazo das ações do governo brasileiro. Sua aprovação precisa passar pelo Congresso.

2. No inciso II do capítulo V do código de Ética e Decoro Parlamentar do Senado, está prevista a aplicação de censura escrita para quem praticar ofensas físicas ou morais a qualquer pessoa, no edifício do Senado, ou desacatar, por atos ou palavras, outro parlamentar, a Mesa ou Comissão, ou os respectivos presidentes.

3. O procurador Luiz Francisco de Souza está sendo processado pelo Ministério Público Federal por ter divulgado a gravação com ACM. Segundo a denúncia, houve a quebra de sigilo da atividade investigativa (Folha de S.Paulo, 03/08/2001).

4. No inciso III do artigo $6^{\circ}$ das medidas disciplinares do Código de Ética e Decoro Parlamentar do Senado, é considerada falta grave passível de punição: revelar conteúdo de debates ou deliberações que o Senado ou Comissão haja resolvido que devam ficar secretos.

\section{REFERÊNCIAS BIBLIOGRÁFICAS}

AMORIN NETO, O. "Os partidos e o Ministério da Produção: um erro de cálculo presidencial". Boletim de Análise Conjuntura Política. Belo Horizonte, Departamento de Ciência Política da UFMG, n.2, dez. 1998.

ARANTES, R.B. Ministério público e política no Brasil. Tese de Doutorado. São Paulo, Faculdade de Filosofia, Letras e Ciências Humanas da USP, 2000.

BANCO MUNDIAL. "O Estado num mundo em transformação". Relatório sobre o Desenvolvimento Mundial. Washington, 1997.

BEZERRA, M.O. Corrupção - um estudo sobre poder público e relações pessoais no Brasil. Rio de Janeiro, Relume-Dumará e Anpocs, 1995.

CATANHÊDE, E. O PFL. São Paulo, Publifolha, 2001.

CHAIA, V. "Escândalos políticos: parte do jogo?" In: CHAIA, V. e CHAIA, M. (orgs.). Midia e política. São Paulo, Educ/Neamp, 2000, p.13-7.

CHAIA, V. e TEIXEIRA, M.A. "Máfia dos fiscais e as estrelas da cidadania”. In: CHAIA, V. e CHAIA, M. (orgs.). Op.cit., 2000.

EISENBERG, J. "Quem manda? O presidente, os partidos e a formação do gabinete presidencial". Boletim de Análise Conjuntura Política. Belo Horizonte, Departamento de Ciência Política da UFMG, n.2, dez. 1998.

FONSECA, F.C.P. e SANCHEZ, O.A. Guia: mecanismos de combate à corrupção e de apoio à cidadania no Estado de São Paulo. São Paulo, Cedec, 2000.

FUNDAÇÃO KONRAD-ADENAUER. "Os custos da corrupção". Cadernos Adenauer. São Paulo, n.10, 2000.

RETTER, J.D. Anatomy of a scandal - an investigation into the campaign to undermine the Clinton presidency. Los Angeles, General Publishing Group, 1998.

RIBEIRO, R.J. A sociedade contra o social - o alto custo da vida pública no Brasil. São Paulo, Companhia das Letras, 2000.

ROSE-ACKERMAN, S. Corruption and government - causes, consequences and reform. USA, Cambridge University Press, 1999.

SCHILLING, F. "O estado do mal-estar: corrupção e violência". São Paulo em Perspectiva. São Paulo, Fundação Seade, v.13, n.3, jul.set. 1999, p.47-55. 
SILVA, M.F.G. da. A economia política da corrupção: o escândalo do orçamento. São Paulo, Núcleo de Pesquisa e Publicação (NPP) da FGV-SP, 1995.

SPECK, B.W. "Mensurando a corrupção: uma revisão de dados provenientes de pesquisas empíricas". In: FUNDAÇÃO KONRADADENAUER. Op. cit., 2000, p.9-45.

TEIXEIRA, C.C. A honra da politica. Rio de Janeiro, Relume-Dumará, 1998.
THOMPSON, J.B. Ideologia e cultura moderna - teoria social crítica na era dos meios de comunicação de massa. Petrópolis, Editora Vozes, 1995.

. A mídia e a modernidade - uma teoria social da mídia. Petrópolis, Editora Vozes, 1998.

Political scandal: power and visibility in the media age. EUA/GB, Blackwell Publishers, 2000. 